UDC 332; DOI 10.18551/rjoas.2022-01.12

\title{
ANALYSIS OF COASTAL TOURISM DEVELOPMENT IN SOUTH SULAWESI, INDONESIA: A CASE STUDY OF HUBAT BEACH AND BULOKKONG BEACH
}

\author{
Arafandi A.M.* \\ Postgraduate Program, Planning and Regional Development, University of Hasanuddin, \\ Makassar, Indonesia \\ Munir Ahmad, Mahyuddin \\ Graduate Schools, University of Hasanuddin, Makassar, Indonesia \\ *E-mail: arafandi@gmail.com
}

\begin{abstract}
This research analyzed the reality of the development of beach tourism in South Sulawesi, namely Hubat Beach in Sanjai Village, Sinjai Regency, and Bulokkong Beach in Bua Village, Sinjai Regency. Informants involved representatives are the Tourism Office, Village Head, Community and Business Actors who are stakeholders of beach tourism. The type of research used is qualitatively descriptive with a case study approach and data collection using in-person interviews with informants. The results showed that first; the natural resources of Hubat beach tourism and Bulokkong beach have their uniqueness. Second, artificial resources on beach tourism are managed by the village government. Third, destination management organizations among stakeholders do not work effectively. Fourth, regulations and human resources are inadequate. Fifth, destination marketing is not yet widespread.
\end{abstract}

\section{KEY WORDS}

Tourism development, coastal tourism, Hubat beach, Bulokkong beach.

Tourism development is a development that must be planned thoroughly so that it can have a good impact on the local community. Law No. 10 of 2009 stipulates that tourism development aims to encourage equitable opportunity to strive and benefit and be able to face the challenges of changing local, national, and global life. According to Pajriah (2018), in addition to the engine of economic driving, tourism is an attractive vehicle to reduce unemployment, as well as increase the introduction and marketing of local products to improve the welfare of the community.

Tourism is a source of income that can be constantly renewed and rejuvenated, this form of rejuvenation of tourist areas can be in the form of renovations, and regular maintenance, therefore tourism is an important investment in the non-oil and gas sector for Indonesia (Rahayu et al., 2015). Indonesia as an archipelago with its coastline has the development of famous beach tourism to foreign countries. For example, beautiful beaches in Bali, Labuan Bajo in Lombok, Raja Ampat in Papua, and places to dive in Wakatobi and Bunaken.

The success of these beach tours should be a trigger for the development of other tourism throughout the region. As for the development of beach tourism in Sinjai Regency, there is no leading destination for both adequate facilities and activities on the destination object. Therefore, on weekends or holiday season people tend to visit the beach tourism of neighboring Bulukumba Regency (Bira Beach) which is still within the same waterfront line.

Sinjai Regency has beach tourism that is no less interesting than the beach tourism on Bira beach, the problem is that beach tourism in Sinjai Regency has not been managed optimally so that it has an impact on the interest of tourist visits that are still low. Seeing these conditions, researchers are interested in researching the problem of beach tourism that still requires further attention. In addition, beach tourism cannot be managed properly without the support of stakeholders. 
The role of stakeholders in tourism development is very important in increasing support and policy-making that will be done for the better. According to Freeman \& Mcvea (2001), it is suggested that if stakeholders have passed support with the policies to be established, it will result in the achievement of strategic success. The statement explained that the role of stakeholders is influential in the effectiveness of development, strategic planning, and performance evaluation.

In examining the reality of the problem of beach tourism, one approach that can be used is through the role of stakeholders including involving representatives from the Tourism Office, Village Heads, Communities, and Business Actors from each beach tour as Informants. Schmeer (2000), describes the characteristics of stakeholders having knowledge and interests related to policy, positions that support or oppose the policy, the potential for alliances with other stakeholders, and the ability to influence policy processes (through the power and/or leadership). Therefore, this research was conducted to look at problems in the development of Hubat beach tourism and Bulokkong beach in the Sinjai Regency. The statement is illustrated because beach tourism is currently still not a priority in the development of tourism in the Sinjai Regency.

\section{METHODS OF RESEARCH}

This research examines the reality of the development of beach tourism so that the method used is qualitatively descriptive with a case study approach. In this study using a single holistic case study research design, the case study is single to be extrapolated as a whole at the tourist attraction (Yin, 2009). The research is located in Sinjai Regency, South Sulawesi Province, precisely on the Hubat Beach attraction located in Sanjai Village, East Sinjai Subdistrict, and Bulokkong Beach located in Bua Village, Tellulimpoe Subdistrict. Data collection techniques through observation, interview, and documentation or audiovisual methods. As for the data collection instruments in this study is "researchers themselves". Researchers interpret data analysis techniques that refer to Yin (2009). The stages of data analysis of findings related to the development of coastal tourism are data collection, data reduction, data grouping, data interpretation, and conclusion withdrawal. The research informant involved stakeholder representatives from the Tourism Office, Village Head, Community and Business Actors of each beach tour and was determined using purposive sampling techniques.

\section{RESULTS AND DISCUSSION}

Analysis related to the findings conducted during the research process on Hubat beach tourism and Bulokkong beach in Sinjai Regency. The results showed the conditions faced in Hubat beach tourism and Bulokkong beach which included: 1) Natural Resources, 2) Artificial Resources, 3) Destination Management Organizations, 4) Situation Conditions and 5) Destination Marketing.

The existence of both tourist attractions, namely Hubat beach and Bulokkong beach, is categorized as a natural resource because it is caused by natural factors or conditions due to natural phenomena. The recognition of informants, both Hubat beach tourism and Bulokkong beach has their unique nature that becomes potential in tourism marketing. Hubat Beach with the potential of mangrove forests along with its beaches and Bulokkong beach with cliff contours on the beach. With the potential to differentiate between Hubat beach and Bulokkong beach, it can be used to provide a choice of beach tourism offers that can guarantee the tourism experience in Kab. Sinjai.

Dwyer et al. (2014) suggest that resources are attributes of destinations that attract visitors and the occurrence of tourism visits. Core resources are divided into two types Endowed and Inherited. Endowed resources can be classified as Nature (mountains, lakes, beaches, rivers, climate, etc.) or Culture/Heritage (cuisine, crafts, languages, customs, architectural heritage, belief systems, and the like). 
Naturally created tourist attractions, namely Hubat beach and Bulokkong beach tourism have different potential, so it becomes an important asset to the competitiveness of tourism offered to tourists, especially beach tourism. Natural resources generally affect tourist attractions, but natural resources on both beaches have not been seen as effective at increasing the number of visits. Therefore, Hubat beach and Bulokkong beach tourism need development to support the attractiveness of natural resources.

The development carried out on Hubat beach tourism and Bulokkong beach is known in the form of the construction of facilities including gazebos, bridges, platforms, and toilets. The construction of the facility according to the informant was carried out by the village government by involving personnel from the local community who were around the location of the tourist attraction. The village government conducts the development of beach tourism by relying on the allocation of Village Funds. The allocation of village funds is regulated in the Regulation of the Minister of Villages, Development of Disadvantaged Regions, and Transmigration Number 6 of 2020 on the Use of Village Funds.

Gazebos, bridges/platforms, and toilets categorized as artificial resources are found in both attractions, namely Hubat beach and Bulokkong beach to support visitor activities to be more diverse. The facilities are enough to support the activities of visitors to relax. However, obstacles such as places of worship (mosque) do not yet exist and the availability of clean water for toilets has not been smooth to inhibit tourist activities to spend longer in the location or when used as a gathering place. Dwyer et al. (2014) explain that the resources created include attributes such as accommodation, restaurants, organized tours, transportation, special events, and a variety of activities available, entertainment, and shopping. Artificial resources make it possible to facilitate visits and add value to the tourism experience.

The destination management organizations on Hubat beach and Bulokkong beach discussed during informant interviews include planning and development, coordination, monitoring, and evaluation. Some of the informants encountered mentioned that the Village Government played a role in determining the planning of the development of Hubat beach and Bulokkong beach.

The Local Government or tourism office does not have the authority in planning the development of Hubat beach tourism and Bulokkong beach because it is a village asset, but still supports the existence of beach tourism. The tourism office in supporting tourism managed by the village government is through The Regional Regulation (Perda) Kab. Sinjai Number 19 of 2019 on the Tourism Development Master Plan (RIPPAR) year 2018-2033. The regulation is intended so that tourism management managed by the village government can be done more organized.

According to Dwyer et al. (2014), public sector destination management activities include the development of national tourism strategies, marketing by national tourism organizations, national and regional labor programs, environmental protection laws, climate change mitigation and adaptation policies, etc. The regulation issued by the local government is expected to serve as a guide in the management of tourist destinations carried out by the village government or local communities.

Coordination between elements on Hubat beach and Bulokkong beach, namely the results of informant interviews revealed that coordination between elements to tourist destinations is still minimal. The development carried out by the village government has not involved coordination from business actors or the community. It can be known from the development that does not get input or needs from the place for business actors are not yet available. The non-involvement of some elements in planning can reduce awareness and participation in the village government's work program. According to Dwyer et al. (2014), it is necessary to ensure coordination and cooperation between different institutions, authorities, and organizations at all levels and if the responsibilities of each stakeholder group can be determined and complement each other.

Regarding monitoring and evaluation of tourist destinations, it has not been done specifically. Some informants mentioned that the village government has not specifically conducted monitoring and evaluation of the development of tourist destinations that have 
been made. In addition, tourism management managed by the village is still not fully organized, such as officers who stand guard or make levy withdrawals are not always there.

Other issues regarding land used in tourist destinations, some are still owned by the community and related to land acquisition or land grants are still waiting for decisions from the village government with the community. However, from the interview of the informant of the concerned community admitted willing to release the land to the village government of course with negotiations that benefited each other (fair).

Ineffective planning and development, coordination between elements, and the lack of monitoring and evaluation processes are considered to affect the competitiveness of destinations. According to Mira et al. (2016), the existence of destination management organizations is important for the same reasons both internal and external or even international management, this organization has a relevant role in the development of strategic management models, which can define objectives and action plans, recognize the public as valuable resources, implement a system of assessment and monitoring of results.

The condition of the situation is the state of the environment around tourist destinations such as security, safety, and human resources. Informants responded that security and safety have no guarantees on tourist destinations, but if there are unexpected events it is coordinated with the village government or polsek and koramil. Community informants from Hubat beach told that there had been a riot when the student institution's activities held deliberations at the place but it was successfully remanded in after the police intervened.

This condition illustrates that there is no firm guarantee for tourists visiting tourist destinations both legally and technically such as lifeguards (beach supervisors) are also not yet available. Tourists who visit without supervision tend to act more aggressively so that it can interfere with the comfort of other tourists and tourist destinations. For example, environmental pollution by littering, carrying dangerous items such as sharp weapons and liquor. As Dwyer et al. (2014), state-of-the-world conditions are forces in the external environment that have an impact on tourism visits and the competitiveness of tourist destinations.

One form of human resource development is through training. Recognition of informants, the tourism office several times conducted tourism training. The last training was held with the theme of destination governance and took place in the Kab. Sinjai meeting hall. The training was held with participants sent by the village government through invitations from the tourism office to each special village that has a tourist attraction.

This condition is considered less effective by some informants because not all tour managers get training and tend to be sent to people who are unable to apply it. According to Mira et al. (2016), comparative advantage is a strong determinant of the position of destinations in attracting tourists, but some factors need to be analyzed such as skills or knowledge of human resources as well as the orientation of social and cultural variables of each tourist destination.

Destination marketing is generally done with the promotion of tourist destinations. From the interview of informants, it is known that the village government has never conducted tourism promotion activities at Hubat beach and Bulokkong beach. The village government only relies on visitors so that tourism is promoted through social media. Meanwhile, the tourism office has conducted promotional activities such as expo or exhibitions at the provincial level. The promotion is not enough for beach tourism destinations Hubat beach and Bulokkong beach because the promotion is done more focused on tourism managed directly by the Tourism Office.

The informant explained that the public or visitors unconsciously play a role in promoting tourist destinations through the internet with their posts on social media such as Facebook and Instagram. Some visitors who come also get tourist location info on social media with the help of online maps. In addition, the role of media involved by tourism agencies in promoting tourist destinations for example in managing official account content on social media such as Facebook, Instagram, and Youtube. As Dwyer et al. (2014), stated that trends in destination competitiveness can be linked to various private and public sector 
initiatives or other variables that allow destination managers to identify the needs of their destinations that require special attention.

\section{CONCLUSION}

Based on research problems, research objectives, and research findings, the conclusion of this study is as follows: First, the natural resources of Hubat beach tourism and Bulokkong beach have their uniqueness. The uniqueness is in the form of mangrove plant areas on Hubat beach, while the cliff area on Bulokkong beach. Second, the artificial resources of beach tourism are managed by the village government. Thus, the construction of facilities at the tourist site is also managed by the village government. The local village government conducts the development of beach tourism by relying on the allocation of Village Funds obtained from the Center (Ministry). Third, the organization of destination management among stakeholders is a miscommunication that causes the development of beach tourism to be less developed and does not run effectively. The village government and the community expect the development to be carried out by the local government, but this condition is contrary because the local government does not want to build beach tourism as long as the beach location is still not given to the local government. Fourth, inadequate regulations and human resources. Conditions related to safety and safeties that have not been guaranteed are also affected because the community around beach tourism has not received human resource training and orientation to the existence of beach tourism. Fifth, destination marketing is not yet widespread. Destination marketing is quite helped by the internet where visitors know the existence of beach tourism from social media but also an initiative is needed to keep the trend of Hubat beach and Bulokkong beach more widely known. Beach conditions that look monotonous, miscommunication between stakeholders, and the absence of inadequate human resource development around beach tourism so that the positive trend of tourist visits is not maintained. Therefore, it is expected to increase the construction of facilities, improve coordination among stakeholders, improve the understanding of the community around beach tourism about tourism management, and increase promotion.

\section{REFERENCES}

1. Dwyer, L., Cvelbar, L. K., Mihalic, T., \& Koman, M. (2014). Integrated Destination Competitiveness Model: Testing Its Validity and Data Accessibility. April. https://doi.org/10.3727/108354214X13927625340073.

2. Freeman, R. E., \& Mcvea, J. F. (2001). A Stakeholder Approach to Strategic Management. Darden Graduate School of Business Administration University of Virginia Working Paper No . 01-02, January. https://doi.org/10.2139/ssrn.263511.

3. Mira, M. R., Moura, A., \& Breda, Z. (2016). Destination competitiveness and competitiveness indicators: Illustration of the Portuguese reality. Tékhne, 14(2), 90-103. https://doi.org/10.1016/j.tekhne.2016.06.002.

4. Pajriah, S. (2018). Peran Sumber Daya Manusia Dalam Pengembangan Pariwisata Budaya Di Kabupaten Ciamis. Jurnal Artefak, 5(1), 25.

5. Peraturan Daerah Kab. Sinjai. (2019). Peraturan Daerah Kab. Sinjai Nomor 19 Tahun 2019 tentang Rencana Induk Pembangunan Kepariwisataan Tahun 2018-2033.

6. Rahayu, S., Dewi, U., \& Fitriana, N. K. (2015). Pengembangan Community Based Tourism Sebagai Strategi Pemberdayaan Ekonomi Masyarakat Di Kabupaten Kulon Progo, Daerah Istimewa Yogyakarta. 3, 1-13.

7. Undang-undang No. 10 Tahun 2009 tentang kepariwisataan, (2009).

8. Peraturan Menteri Desa, Pembangunan Daerah Tertinggal, Dan Transmigrasi Republik Indonesia Nomor 6 Tahun 2020 Tentang Perubahan Atas Peraturan Nomor 11 Tahun 2019 Tentang Prioritas Penggunaan Dana Desa Tahun 2020, (2020).

9. Schmeer, K. (2000). Stakeholder Analysis Guidelines, Section 2. January.

10. Yin, R. K. (2009). Case Study Research: Design and Method (4th ed.). SAGE Inc. 